\title{
INHALT
}

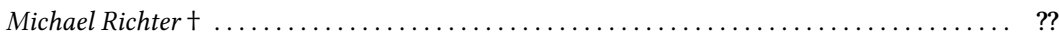

Matthias EgELER: Some thoughts on 'Goddess Medb' and her typological context ........ ??

Beatrix FärBER: Bedeutung und Rezeptionsgeschichte des Foras Feasa ar Éirinn (c. 1634) von Geoffrey Keating (Seathrún Céitinn) ........................... ??

Harald FLOHR: The phenomenon of language contact - English influence on Irish and Welsh found in the translations of Rowling's Harry Potter and the Philosopher's Stone ...... ??

Sergey Ivanov: Three colours of the tree $\ldots \ldots \ldots \ldots \ldots \ldots \ldots \ldots \ldots \ldots \ldots \ldots \ldots$ ??

Ranko Matasović: Dybo's Law in Proto-celtic ............................ ??

Máire Ní Mhaonaigh: A neglected acount of the battle of Clontarf ................ 1

Meidhbhín Ní ÚRDAIL: A poem on the adventures abroad and death of Donnchadh son of Brian Bóraimhe ........................................? ?

William SAYERs: Netherworld and Otherworld in early Irish literature ............. ??

\section{Besprechungen und ANZEigen}

Arbuthnot, S. J. \& G. Parsons: The Gaelic Finn tradition (E. Poppe) ............... ?? Воск, F. et al: Allerlei Keltisches - Studien zu Ehren von Erich Poppe (Р. Смгтн) ....... ?? Boyle, E. \& P. Russell: The tripartite life of Whitley Stokes (1830-1909) (St. Zimmer) .... ?? BREezE, A.: The origins of the Four Branches of the Mabinogi (B. J. LewIs) ........... ?? CArnie, A.: Irish Nouns. A Reference Guide (G. Немprich) .................... ??

Charles-Edwards, T. M. \& R. J. W. Evans: Wales and the wider world: Welsh history in an international context (M. LÖFfLER) ......................... ??

Collis, J.: The Celts. Origins, myths, inventions (S. Junges) .................. ??

Delamarre, X.: Noms de lieux celtiques de l'Europe ancienne $(-500 /+500)$. Dictionnaire

(St. ZIMmer) ............................................. ?

GaItzsch, T.: Das Pferd bei den Indogermanen. Sprachliche, kulturelle und archäologische Aspekte (St. ZIMmer) . .................................... ??

Griffin-WiLson, M.: The wedding poems of Dáibhí Ó Bruadair (T. L. Ó Murchú) ....... ??

Haubrichs, W. \& H. Tiefenbach: Interferenz-Onomastik. Namen in Grenz- und

Begegnungsräumen in Geschichte und Gegenwart (St. ZIMMER) ............... ??

HinRICHS, U.: Handbuch der Eurolinguistik (S. HäUSSLER) . . . . . . . . . . . . . . ? ?

JACOBs, N.: Early Welsh gnomic and nature poetry (St. ZIMMER) ................? ??

Jones, Ff. M.: Y Rhyfel Cartrefol, Huw Morys (M. LöfFLER) .................... ?? 
KIM, R. et al.: Ex Anatolia Lux. Anatolian and Indo-European studies in honor of H. Craig Melchert on the occasion of his sixty-fifth birthday (S. Hutter-BraunsaR) ??

KIstLer, E.: Funktionalisierte Keltenbilder. Die Indienstnahme der Kelten zur Vermittlung von Normen und Werten in der hellenistischen Welt (H.-U. CAIN) .......?? KLUGE, Etymologisches Wörterbuch der deutschen Sprache. Bearbeitet von Elmar SEEBOLD. 25. Auflage (A. LIBERMAN)

Krisch, Th. \& Th. Lindner: Indogermanistik und Linguistik im Dialog. Akten der XIII. Fachtagung der Indogermanischen Gesellschaft ... 2008 in Salzburg (I. BALLes) .. ?? Lochner, Michaela \& Ensemble CANTLON: Sitularia - Klänge aus der Hallstattzeit

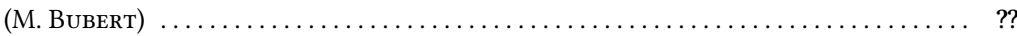

Mac Mathúna, S. \& A. Ó Corráin: Celtic literatures in the twentieth century (P. Sмiтн) ?? Marcantonio, A.: The Indo-European language family: questions about its status

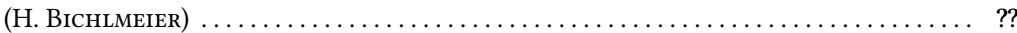

McLeod, W. et al: Bile ós Chrannaibh. A festschrift for William Gillies (B. Meier) ...... ?? MiHAILEsCu-BîrLibA, Lucreţiu: Ex toto orbe Romano: immigration into Roman Dacia; OlteAn, Ioana A.: Dacia. Landscape, colonisation and romanisation (A. FAlileyev) . . . . ?? Ó CRóINín, D.: Whitley Stokes (1830-1909): The lost Celtic notebooks rediscovered (B. MeIER)

Ó MachÁIn, Pádraig (ed.): The Book of the O'Conor Don: essays on an Irish manuscript

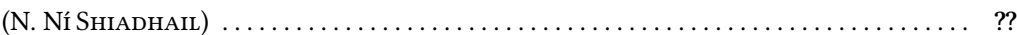

Ó RIAIN, Pádraig: A dictionary of Irish saints (St. ZIMMer) ................... ?? Preston-Matto, L.: Aislinge Meic Conglinne: The Vision of Mac Conglinne (F. Ó BÉARRA) ?? Schulte, M. \& R. Nedoma: Language and literacy in early Scandinavia and beyond

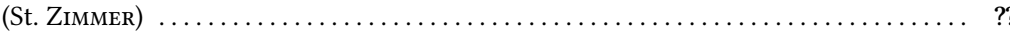

SchweIghöFer, B.: Keltisches Neuheidentum im deutschsprachigen Raum (F. Воск) . .. ? ??

Sims-Williams, P.: Irish influence on medieval Welsh literature (St. Zimmer) ......... ??

Sмітн, Peter J.: Three Historical Poems Ascribed to Gilla Cóemáin (G. Hemprich) . ...... ??

Sterckx, C.: Mythologie du monde celte (St. Zimmer) ........................ ??

Ternes, E.: Brythonic Celtic - Britannisches Keltisch. From medieval British

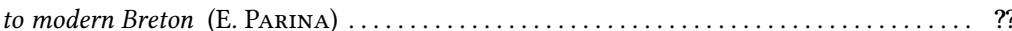

Tolstoy, N.: The Oldest British Prose Literature - The Compilation of the Four Branches of the Mabinogi (A. L. WARWICK) ................................ ??

Widmer, P. \& A. R. Jørgensen: An Buhez Sant Gwenôlé. Das Leben des heiligen Gwenole. Text, Übersetzung und Anmerkungen (J. WeIss, A. Воск) 




\title{
A neglected acount of the battle of Clontarf
}

\author{
Zusammenfassung
}

Brian Ó Cuív bemerkte in seinem Katalog irischer Handschriften in Oxford die Existenz eines kurzen, fragmentarischen Textes, der in der Handschrift Rawlinson B 486 der Bodleian Library in Oxford überliefert ist und den Ó Cuív als ,Bericht über die Schlacht von Clontarf $(A D$ 1014)' beschrieb. Diese Quelle hat bislang nicht die ihr gebührende Aufmerksamkeit erfahren. Hier wird eine eingehende Analyse des Inhalts des betreffenden Textes vorgenommen und sein Verhältnis zu anderen Kompositionen zur Auseinandersetzung bei Clontarf untersucht; eine vollständige Transkription und Übersetzung des Fragments findet sich am Ende des Artikels. Als ein wichtiger Zeuge dieses Zusammenstoßes stützt dieser vernachlässigte Bericht die Existenz einer Bréifne-Version von Cogadh Gáedhel re Gallaibh und liefert wichtige Anhaltspunkte für das Vorhandensein bereits im 14. Th. des Prototyps dessen, was in nachklassischen irischen Texten an Material bezeugt ist, das sich mit Clontarf beschäftigt.

\section{Introduction}

The battle of Clontarf, the 'great war' (cocad mór), as the Annals of Inisfallen (AI) describe it, fought in 1014 between Brian Bórama, king of Munster, and the Norse of Dublin, together with their Leinster allies, features prominently in both medieval and modern historical and literary sources. ${ }^{1}$ Moreover, with the exception perhaps of the brief record of the encounter in that Munster chronicle, $A I$, even the earliest annalistic accounts present their own subjective slant on the event. ${ }^{2}$ These augmented reports informed in turn detailed narrative depictions of the battle, most notably that contained in the twelfth-century eulogy of Brian's life and death in the Uí Briain tract, Cogadh Gáedhel re Gallaibh. ${ }^{3}$ Preserved in three manuscripts, ranging in date from the fragmentary text in the twelfth-century Book of Leinster ${ }^{4}$ to the seventeenth-century copy transcribed by Míchéal Ó Cléirigh from a copy he had previously made of the otherwise unknown Leabhar Chon Chonnacht Uí Dhálaigh, ${ }^{5}$ these witnesses preserve two recensions of the composition. In addition, the lacunose text preserved in what may be a fourteenth-century manuscript, Trinity College Dublin 1319 (H.2.17), ${ }^{6}$ incor-

1 AI 1014.2.

${ }^{2}$ For a discussion of these accounts, see Ní MHAONAIgH 2007: 52-99.

3 ToDD 1867.

${ }^{4}$ LL: 1319-25, lines 39322-550.

5 Brussels, Bibliothèque royale, manuscript 2569-72, fols 103-35; Ó Cléirigh was writing in 1635 at the convent of Donegal transcribing from a copy he had made in March 1628 at Multyfarnham in County Westmeath. Eugene O'Curry made a transcript of this manuscript for Trinity College Dublin which is now shelved as 1408 (H.6.18).

6 TCD MS 1319 (H.2.17), vol. X, fols 350-97; a portion of the text has been lost from the beginning and the end, corresponding to $§ \S 1-5,113-21$ in ToDD 1867. 
porates what may be mid-twelfth-century interpolations concerned with glorifying Bréifne and Uí Ruairc.?

These and presumably other copies of the Cogadh, as well as different accounts of the battle, were drawn on by later authors, including the thirteenth-century Icelander who wove an account of 'Brian's battle' (Brjánsorrosta) skilfully and effectively into his family history of Burnt Njáll. ${ }^{8}$ His Irish contemporary, Muireadhach Albanach Ó Dálaigh, similarly drew inspiration from Brian Bórama's story, if the portrayal of the sinless, sacred king in Aonar dhuit, a Bhriain Banba, really stems from his hand.' Whoever the poet may have been he was familiar with the Cogadh, as was the later creator of Caithréim Thoirdhealbhaigh, a fourteenth-century account of Uí Briain civil strife. ${ }^{10}$ Moreover, Muircheartach mac Toirdhealbhaigh, son of the eponymous hero of the Caithréim who died in 1343, is specifically urged by another poet, Máel Muire Bacach Mac Craith, to fight another cogadh gall re gaoidhealaibh in what must surely be a deliberate echo of Brian's own 'great war.' ${ }^{11}$

More than three centuries after his death in battle, therefore, Brian continued to be held up as a shining example, his glorious demise at the hands of foreigners hailed as an ever relevant heroic ideal. Interest in his activities is, not surprisingly, particularly evident in Munster; yet, as the fourteenth-century transcript of a version of the Cogadh with Bréifne additions indicates, Brian's tale continued to hold universal appeal. Its popularity is further underlined by the existence of a fragmentary composition concerning his and his allies' battalions in another fourteenth-century manuscript, Oxford, Bodleian Library, Rawlinson B 486. Identified as 'an account of the Battle of Clontarf (1014 A.D.)' by Brian Ó Cuív in his catalogue of Irish manuscripts in Oxford, ${ }^{12}$ this short text has not received due attention. My aim here is to analyse its content, and to investigate its relationship with other compositions dealing with the conflict at Clontarf; a complete transcription and translation of the fragment is presented at the end of the article.

\section{The Rawlinson B 486 Text}

Although Clontarf itself does not feature in the fragmentary text, it provides an account of three battalions known from other sources to be present at the battle. Beginning to some extent in medias res, Brian's battalion is presented and its twenty kings enumerated. Munster men are prominent but Connacht nobles are also listed, including some from regions such as Mag Luirg and Conmaicne Mara, not immediately adjacent to Brian's north Munster home territory of Dál Cais. The presence therein of Domnall mac Émín, mórmáer of Alba, accords with chronicle evidence, since he is recorded among the slain on Brian's side in the Annals of Ulster $(A U)$, Chronicum Scottorum (CS) and other interlinked texts. ${ }^{13}$ In the case of the second battalion, of Tuadmumu, the focus moves southwards again and specifically onto

\footnotetext{
7 See Ní Mhaonaigh 1992.

${ }^{8}$ SveINSSON 1954.

9 GoedheEr 1938: 45-59.

10 O'Grady 1929.

11 See Simms 1979: 60.

12 Ó Cuív 2001: 132.

13 AU 1014.2; CS, 252-3; AFM s.a. 1013; ALC 1014, Vol. 1, 12-13; MurPhy 1896: 167.
} 
Dál Cais themselves. Brian's son, Murchad, is said to lead it, assisted by his own son, Tairdelbach, and Brian's nephew, Conaing mac Duinn Cuain. Nonetheless, allies from further afield also form part of this phalanx, including Conmaicne once more, Uí Briúin, Síl nÁeda Sláine and the men of Tethba. Northern kings similarly provide support to the third Desmumu battalion, most notably Airgialla and Fir Manach. Its leaders, however, are Domnall mac Duib Dá Bairenn and Cian mac Maíl Muaid of Eóganacht Rathlinn and the king of the Déssi also belongs to it. After the fourth Munster name, most likely that of the king of Uí Liatháin, Muirchertach mac Anmchada, a chasm occurs in the manuscript. Who else may have been listed in the text or how it may have continued cannot now be ascertained. Nor can the surrounding material in the manuscript assist us: the fragment is followed by an acephalous list of kings of Ireland which, although it begins a new manuscript section, ends with a reference to Brian's great-grandson, Muirchertach mac Tairdelbaig (ob.1119), continuing the Uí Briain theme.

\section{The Manuscript Context}

The manuscript section which ends with our fragmentary text also contains related material, specifically Dál Cais (as well as Eóganacht) genealogies. Other genealogical material contained therein focuses on the various branches of the Múscraige, of whom the Múscraige Tíre in particular, are also prominent in the manuscript as a whole. This emphasis, as well as that on the premier saint of that dynasty, Ruadán, led both Pádraig Ó Riain and Brian Ó Cuív to suggest that it was in Ruadán's church of Lothra that the manuscript was written. ${ }^{14}$ Indeed the scribe of one section (though not that in which our fragment is found), Mac Craith Mac an Ghabhann na Scél, claimed to have written the book for a fourteenth-century prior of the Augustinian house at Lothra, Giolla Ruadháin Ua Macáin..$^{15}$ In this connection, we may note that four of the twenty kings in Brian's battalion are of Múscraige descent. Two of these, Muirchertach mac Cuirc, king of Múscraige Breogain, and Donnchad mac meic Cathail, king of Múscraige Áeda, are also connected with the battle of Clontarf in post-Classical Irish sources ${ }^{16}$ as is Áed ua Dúngalaig, though his description as 'king of Múscraige Tíre' occurs only in the Rawlinson B 486 fragment. The fourth member of the Múscraige, Áed mac Flainn, king of Múscraige Mittaine, appears to be unique to our text.

The North Munster bias of the manuscript provides adequate reason for the inclusion of a text concerning the military manoeuvres of Brian Bórama therein. Brian Mac Mathgamna, king of Thomond between 1369 and 1400, is mentioned in a marginal note and a list of Thomond kings by the manuscript's third main scribe (i.e. neither Mac Craith Mac an Ghabhann na Scél nor the anonymous scribe of our text) concludes with the same king. ${ }^{17}$ Pádraig Ó Riain has noted the prominence accorded to saints Molua and Flannán of the diocese of Killaloe (to which Lothra belonged) in the version of saints' genealogies preserved in the manuscript. Other North Munster saints are also given a prominent position, including St Crónán of Roscrea. ${ }^{18}$

\footnotetext{
${ }^{14}$ Ó RIAIN 1985: xxxiii-iv; Ó Cúív 2001: 122-3.

15 Ó RIAin 1985: xxxiii; Ó Cú́v 2001: 122.

16 See, for example, Ní Úrdail 2011: 110, and further below.

17 Ó Cuív 2001: 123.

18 Ó RIAIN 1985: xxxv.
} 


\section{The Rawlinson B 486 Text and Cogadh Gáedhel re Gallaibh Compared}

Roscrea is similarly accorded prominence in a passage contained in the first part of the Uí Briain propaganda tract, Cogadh Gáedhel re Gallaibh, in which Viking raids are chronicled, a detailed account of a specific incident which happened there being preserved. The exact day on which the invaders arrived is recorded, the feast of saints Peter and Paul, when an ónach was being held. Through the grace of the two saints the Vikings were defeated, Earl Onphile being struck by a stone and killed. ${ }^{19}$ The emphasis placed on this event is noteworthy in what is otherwise, for the most part, a litany of Viking fleets and the places attacked by them.$^{20}$ Standing apart as it does, the Roscrea attack is likely to have formed part of a local record employed by the compiler of the Cogadh and I have drawn attention in the past to other information unique to the narrative which was most likely drawn from the same source. ${ }^{21}$ This includes a reference to Ruadán's shrine at Lothra being broken not preserved elsewhere. ${ }^{22}$

Quite apart from the obvious thematic connection between the fragmentary text in Rawlinson B 486 and the Cogadh, therefore, both display an affinity with the same region. Furthermore, in the case of the description of the second battalion (cath Tuadmuman, according to the later text), a link between them can be demonstrated with relative ease. Apart from the fact that the Dál Cais troop is described (alliteratively) as being dichra in Rawlinson B 486, all other information contained in the fragment could have been derived directly from the earlier Uí Briain tract. ${ }^{23}$

$\underline{\text { Rawlinson B 486: }}{ }^{24} \S 3$ Tucad $h$ a dosach don damraigh dēin, dïfhuiling, dīchra 7 don gamanraid $h$ glain, gasta, gērata, galaigh, gnīmaigh gairgbeodha .i. do Dāil Caiss curata, comramaigh ${ }_{7}$ do $\mathrm{C}[\mathrm{h}] \mathrm{la}(\mathrm{i}) n$ daibh Luighdheach $\operatorname{arc}[\mathrm{h}] \mathrm{eana}$.

$\underline{\operatorname{Cog} a d h}{ }^{25}$ Tuccad imorro tosach catha Briain, ocus mathi Erend arcena du[n] ${ }^{26}$ damraid dein, diulaing remrati, dun gamandraid glain, gasta, ge[ra]ta, galaig, gnimaig, gargbeoda .i. do Dálcais curata comrumaig, ${ }^{27}$ ocus do clannaib Luigdeach arcena.

19 ToDD 1867: 14-17.

20 The passage immediately following the Roscrea incident is typical in this regard (ToDD 1867: 16): Tanic iarsin longes tri ficit long do Normandaib for Booind, ocus ro inrit Bregha leo, ocus Midi. Tanic longes [aile] cor gab for Loch Ecach, ocus ro hinred leoside co hArd Macha. Tanic longes ele cor gabside for abaind Liphi, ocus ro hindred Mag mBreg leo, ettir tuaith ocus cill. 'There came after that a fleet of sixty ships of Northmen upon the Boyne; and Brega and Mide were plundered by them. [Another] fleet came and attacked Loch nEchach and they plundered as far as Armagh. Another fleet came and settled upon the River Liffey and Mag mBreg was plundered by them, both laity and clergy'.

${ }^{21}$ Ní MhaONAigh 1996: 123-5.

22 Todd 1867: 16: ro hinred leo ... co Ros Cre, ocus co Lothra, co ro brisetar scrin Ruadan ... 'they plundered ... as far as Roscrea and to Lorrha and the broke Ruadán's shrine ....

23 Correspondences are marked in bold font here and elsewhere. In this instance, the evidence of the Rawlinson B 486 fragment enables us to emend the Cogadh's meaningless geta to gérata.

26 ToDD does not insert the definite article which is, however, present in the reading of the later Ó Cléirigh manuscript.

27 ToDD reads conrumaig but the same abbreviation is used to represent con and com by the scribe. 
Close correspondences between the two versions are also revealed in the passage immediately following this one in both texts, introducing Brian's son, Murchad, as the leader of the troop, alongside Tairdelbach his son, and Murchad's cousin, Conaing, together with three protectors of Brian:

Rawlinson B 486: §4 Ro baī rompu sin Achtair indtamlaighteach na hĒrend 7 na $\mathrm{h} \bar{A} \mathrm{~d} h \mathrm{am} \boldsymbol{h c}[\mathrm{h}]$ lainde ilc[h]enēalaigh, allata $\operatorname{arc}[\mathrm{h}]$ eana .i. Murcad $h$ mac Briain, eo rosa raicg $h$ daid $h$ e (?) na $h \bar{E}$ rend 7 ceand gaile 7 gaisgid $h$ enig 7 eangnamha na hĒrend 7 triath 7 treteall 7 trēnmílid $h$ fhe $a r$ in talman re ræ 7 re roimeas. Dōig ni ármid seanc[h]aidhe na [n]Gædheal co $\mathrm{m}[\mathrm{b}]$ eth donn $\bar{A} d h a m h c[h] l a i n d$ 'na aimsir fēin æn duine ro congēbad $h$ sciath co freastal imuallta fris. 7 Baí ar æn fris a mac fēin .i. Toirdelbach in mac aissi 7 in rīghdomna is fearr ro baí a nĒrind.

§ 57 Tānic mac Duind Cuan mac brāthar Bria[i]n in mac is doch(i)u le Brian baí in hĒrind .i. tromtānaistte na hĒrend 7 rīgh díles Desumhan; 7 Níall Ō Cuind 7 Eochaid $h$ Ō Dūnaghaid $h$, flait $h$ Clainde Scandlāin ${ }_{7}$ Cū Duilig $h$ mac Ceindēdigh, trī cūlc[h]oimēdhaigh Briain.

Cogadh: ${ }^{28}$ Bai rompu side in Hechtoir intamlaigtech ilbuadach na hAdam clainni ilcenealaichi allatai .i. Murchad mac Briain, eo Rossa, rigdraidi Erend; cend gaili, ocus gascid, ocus gnimrada, enig ocus engnuma, ocus aebdachta fear talman, re re, ocus re remis; daig ni armit senchaidi Goedel co mbeth don Adamclaind re re fein oen duni no chongbad sciath comrestail imbualta do. Batar, dna, ar oen ris sin, .i. Tairdelbach a mac, in rigdomna a aisi [is] ferr bai in nErind, ocus Conaing mac Doncuan, in tres duni is tochu ri Brian bai i nErind, ocus Niall Ua Cuind, ocus Eochu mac Dunadaig ocus Cudullig mac Cendetig, tri cometidi Briain ...

They are not, of course, identical and minor differences between them suggest that no extant version of the Cogadh was the direct source. ${ }^{29}$ This is underlined by the fact that following these passages, both texts diverge. The Rawlinson B 486 fragment enumerates Dál Cais nobility; however reference is then made in the earlier tract to other Munster chieftains ${ }^{30}$ and while both the king of the Déssi and Uí Liatháin also feature in the Rawlinson B 486 account, they form part of the specifically Desmumu battalion. A short description of the Connacht battalion follows in the Cogadh. ${ }^{31}$ Tadc Ua Cellaig of Uí Maine and Máel Ruanaid Ua hEidin of Uí Fhiachrach Aidni are also common to both texts (and indeed feature in all accounts of the Clontarf conflict); they are found among the twenty kings of Brian's battalion, however, in Rawlinson B 486.

${ }^{29}$ The passages just cited, however, appear closer to the version of the Cogadh in Trinity College Dublin manuscript 1319 (upon which Todo based his text) than to that in the later Ó Cléirigh Brussels manuscript. The adjectives, curata and comramach, describing Dál Cais are not present in the later Ó Cléirigh manuscript. In addition, glain, gasta, ge[ra]ta appear as gloin glésta, gasta in Ó Cléirigh's text. Both TCD MS 1319 and Rawlinson B 486 refer to Hector as being 'of the renowned, many nationed children of Adam', whereas Ó Cléirigh reads Echtar intsaimlaigtech na hErenn. By contrast, however, Brian's protectors are termed cúlcomedaidhe in Ó Cléirigh's text, as they are in Rawlinson B 486.

${ }^{30}$ Todd 1867: 166-7.

31 Todd 1867: 168-9. 


\section{The Rawlinson B 486 Text and Genealogical Material Compared}

Whereas the Cogadh turns its attention to kings from other regions, the focus in Rawlinson B 486 on Dál Cais chieftains at this point in the narrative accords it a local flavour. Moreover, there is a direct link with the preceding section, since sons of Brian himself, and the descendants of his brother, Donn Cuan, are included in both. The list of Dál Cais nobility is dependent on genealogies, as indicated by its structure. Commencing with Brian's father, Cennétig mac Lorcáin (who died more than sixty years before the battle of Clontarf), ${ }^{32}$ it moves on to his sons, Brian's brothers, Donn Cuan, Echthigern and Ánluan. It then steps back a generation to Coscrach mac Lorcáin, brother of Cennétig, including among his cland, three sons of his, Senchán, Máel Ruanaid and Aingid, but also Ócán who was in fact a son of Aicher son of Coscrach. The next four names are of Ócán's generation, being sons of Brian Bórama himself: Tadc, Domnall, Conchobar and Flann. Of Brian's other two sons, Murchad features prominently in the text elsewhere, as we have seen above. That Donnchad, is not referred to may well be deliberate, aligning the fragment with the branch of the Clontarf tradition (expressed most forcefully in the Annals of Loch Cé) portraying Brian's oldest son in a negative light. ${ }^{33}$

Six of the next eight personages named are associated with the Dál Cais kindred, Uí Doborchon, and form two son-father-grandfather groupings, though this is not indicated in the text. Donnchad, Domnall and Gilla Pátraic appear next to one another with youth given priority; ${ }^{34}$ the second grandfather figure, Menma Adar, is separated from his grandson, Gormgal, who in turn is placed alongside his father, Cathán, though not specifically connected with him. ${ }^{35}$ Between Menma Adar and Donnchad (mac Domnaill meic Gilla Pátraic) Dedad mac Domnaill who is also of Uí Doborchon ${ }^{36}$ and Máel Meda mac Gilla Báetáin of another Dál Cais group, Cenél Báeth, are found. ${ }^{37}$

The text then returns to Brian's immediate family, specifically to his brother, Donn Cuan and the latter's descendants, suggesting that Uí Doborchon material may well have been centrally placed to draw attention to it. Three of what we know to have been six of Donn Cuan's sons are listed ${ }^{38}$ Longargán, Riacán and Célechair. A fourth, Conaing, though described merely as mac Duinn Cuain, occurs elsewhere in the fragment as king of Desmumu; ${ }^{39}$ the two sons called Cennétig do not appear. Uí Thairdelbaig nobles follow: Fiangalach and Indrechtach who were father and son, ${ }^{40}$ though again their relationship is not made explicit in the text; a pair of brothers, Duibcenn and Beollán, sons of Áed mac Duibcinn, who are also not specifically

\footnotetext{
32 AI 951.

33 ALC 1014, Vol. 1, 8-11; Ní Mhaonaigh 2007: 61-2, 101-2.

34 Dúnchad m. Domnaill m. Gilli Patraic: CGH: 243 (Rawlinson B 502, 153 b 10-12).

35 CGH: 243 (Rawlinson B 502, 153 b 11).

${ }^{36} \mathrm{CGH}$ : 244 (Rawlinson B 502, 153 b 17), under the heading De genelogia iarborcun.

37 CGH: 244 (Rawlinson B 502, 153 b 21); see also Ó DonNCHADHA 1940: 316.

38 Sé meic dano oc Dund-chuan mac Ceinnètich ...: CGH: 238 (Rawlinson B 502, 152 b 49).

${ }^{39} \mathrm{He}$ is accorded the same title in the Cogadh (Tond 1867: 184). Note also the similarly between his depiction as 'tromtānaistte na hErend' in the Rawlinson B 486 fragment and his description as righ thanaiste ... na hErenn in the account of his death in the earlier text (ToDD 1867: 208).

40 CGH: 238 (Rawlinson B 502, 152 b 53); Ó DonNCHADHA 1940: 303.
} 
connected with one another; ${ }^{41}$ and Ruaidrí mac Cétfada who died five years before the battle of Clontarf. ${ }^{42}$ The next person in the list, Niall buide mac Indrechtaig was a son of Indrechtach mac Tuathail meic Fhlainn, according to Dál Cais genealogies; ${ }^{43}$ his brother, Cuilén may have been given the erroneous patronymic, Cathalán, in the text. Separating them is the otherwise unknown, Ragnall mac Ócáin. Eochaid ua Loingsig who follows Cuilén in the list similarly does not appear in published genealogies. He is followed in turn by two kings of Corco Modruad. The first, Máel Sechnaill mac Conchobair, is designated king of the western part (iartharach) of that territory, while his companion, Amlaíb mac Lochlainn, is associated with the eastern part (airtherach) of the region. The latter, however, was slain a decade or so before the battle of Clontarf, fighting alongside a different king of Corco Modruad, Conchobar mac Maíl Shechnaill. ${ }^{44}$ In the light of this, notwithstanding the chronological discrepancy, it may be that Máel Sechnaill mac Conchobair appears as an error here for Conchobar mac Maíl Shechnaill. Alternatively, the man intended may have been a son of the latter, Máel Sechnaill mac Conchobair, who was killed as king of Corco Modruad in 1027, fighting alongside Brian Bórama's son, Donnchad..$^{45}$ Conchobar had two other sons at least, Lochlainn and Cathal, who were murdered together treacherously (tre fell) the year after the battle of Clontarf. ${ }^{46}$ Thus, Amlaíb mac Lochlainn may have been a son of the first of these. If so, he was killed alongside his grandfather in 1003 though this relationship is not noted in the annal entry recording the slaying of both men. Such an association with power may explain his role as sub-king over the eastern part of the territory. Aicher mac Lorcáin is next in the list and while his precise identification is unclear he is specifically associated with another Dál Cais branch, Uí Chormaic, in the text.

A substantial number of these Dál Cais names are also preserved in a parallel passage in Keating's Foras Feasa ar Éirinn: ${ }^{47}$

${ }^{41}$ CGH: 238 (Rawlinson B 502, 153 a 1-2); Ó DonnchadHa 1940: 304.

42 AI 1009.4: Bas Ruadríg m. Cétfada.

${ }^{43}$ CGH: 236 (Rawlinson B 502, 152 b 15); Ó DonnchadHa 1940: 236, 306.

${ }^{44}$ AI 1003.3: Guin Conchobuir m. Maíl Shechnaill, ríg Corcu Mruad 7 Amlaib mc. Lochlaind 7 Aichir Úa Traichthech i n-iarthar Chonnacht 'The slaying of Conchobar son of Máel Sechnaill, king of Corco Modruad, and of Amlaíb, son of Lochlainn, and of Aicher Ua traigthech in the west of Connachta'.

45 AFM s.a. 1027 (Maolsechloinn, mac concobhair, tigherna CorcoModhuradh). He is termed Maolsechlainn .H. Concupair in CS: 266-7, while the Annals of Tigernach has the more general, Máel Sechnaill, son of the king of Corco Modruad (mac righ Corcomruadh): STOKES 1896: 367. AI 1027.5 mistakenly calls him Conchobuir m. Maíl Shechnaill and does not associate his death with the hosting by Donnchad mac Briain into Osraige recorded in the previous entry.

${ }^{46}$ AI 1015.4; the annalist claims that cách díb i ndegaid alaile i rrígu Corcu Mdruad 'one followed the other in the kingship of Corca Modruad', a role they presumably adopted on the death of their father, Conchobar, in 1003.

47 DinneEn 1908: 272-3: 'Thither [Áth Cliath to fight the battle of Clontarf] went also the sons of Cinnéide son of Lorcán, Ánluan, Lachtna, Coscrach, Lorcán, Seanchán, Ógán, Maolruanaidh and Aingidh; Murchadh son of Brian, and his son, Toirrdhealbhach and five of Murchadh's brothers, to wit, Tadhg, Donnchadh, Domhnall, Conchubhar and Flann. Thither went in like manner the sons of Donn Cuan son of Cinnéide, to wit, Longargán, Céilechair, Cinnéide, Fiangalach, Innreachtach; Eochaidh son of Innreachtach, and Duibhgheann son of Eochaidh and Beollán and as many of their officials and followers who came with them'. 
FFÉ: Tángadar ann fós mic Cinnéididh mic Lorcáin, Annluan, Lachtna, Coscrach, Lorcán, Seanchán, Ógán, Maolruanuidh, is Aingidh, Murchadh mac Briain is a mhac Toirrdhealbhach is cúigear dearbhráthar Murchadha .i. Tadhg, Donnchadh, Domhnall, Conchubhar is Flann. Tángadar ann mar an gcéadna clann Duinn Cuan mic Cinnéididh .i. Longargán Céileachair Cinnéide Fianghalach Innreachtach Eochaidh mac Innreachtaigh is Duibhgheann mac Eochach is Beollán, is ar lean díobh-so da n-aos gráidh is da lucht leanamhna.

Rawlinson B 486: $\S_{7}$ Ceindēdig $h_{7}$ Dund Cuan, Aichtighearnd $h_{7}$ Ānluan; 7 Coscrach mac Lorcāin cona (a)c[h]laind (7) Seanc[h]ān 7 Ōgān 7 Mæl Ruanaidh 7 Angid $h$;Tadg 7 Domnall 7 Conc[h] ubhur 7 Fland; 7 Meanma Adhar 7 Dedad $h$ mac Do $m$ naill $\neg$ Mæl Mead $h$ a mac Gilla Bædāi $n_{7}$ Don $n c[\mathrm{~h}] \mathrm{ad} h_{7}$ Do $m$ nall 7 Gilla Pātraic 7 Gormgall 7 Cathān; 7 Du(i) $n$ d Cuan, Longargān 7 Ríg ruan 7 Cēlechair; ${ }_{7}$ Fiangalach 7 Indrachtach 7 Dui(d)[b]c[h]eand 7 Beollān 7 Ruaidhrí mac Cētfadha 7 Níall buidhi mac Indrachtaigh 7 Raghnall mac Ōgāin $\rceil_{7}$ Cuilēn mac Cathalāin ${ }_{7}$ Eochaid $h$ ua Longsigh ${ }_{7}$ Mælseachlaind mac Conc[h]ubhu[i]r, rīg $h$ Corcu Mruad $h$ íart[h]arach 7 Amlaim $h$ mac Lochlaind, rīg $h$ Coru Mruad $h$ airt[h]arach ${ }_{7}$ Aichear mac Lorcāin, rīgh Ō Cormeic ...

Uí Doborchon material is not present in Keating's text, underlining the fact that its presence in Rawlinson B 486 may reflect a particular interest on the part of its author. Nonetheless, an overlap of eighteen names among the remainder indicates, at the very least, access to the same genealogical source. Elsewhere Keating specifically acknowledged Cogadh Gáedhel re Gallaibh for his information on Vikings in Ireland. ${ }^{48}$ Might these names, therefore, have been preserved in a now lost version of this source? The parallel material in the Cogadh and the Rawlinson B 486 fragment already alluded to concludes with a reference to Brian's nephew, Conaing mac Duinn Cuain, one of the men most valued by the Munster king, followed by mention of Brian's three guards. ${ }^{49}$ After naming the king of Corco Baiscinn, Domnall mac Diarmata, the Cogadh compiler concludes his account of Brian's own dynasty by glancing in passing at forgla laith gaili ocus gascid Dál Cais ar oen riu sin 'the greater part of the men of valour and bravery of the Dál Cais along with them'.$^{50}$ It is certainly conceivable that another version of the text might have included an expanded list of 'the greater part' of those valorous Dál Cais warriors which the fourteenth-century scribe of the Rawlinson B 486 text, or a predecessor, could have had at his disposal and the parallel passage in Keating may provide some support for this conjecture.

\section{The Rawlinson B 486 Text and the Bréifne-Cogadh Compared}

Yet other evidence suggests that the author of the Rawlinson B 486 text may have been familiar with what I have termed the Bréifne edition of Cogadh Gáedhel re Gallaibh put together sometime around the middle of the twelfth century in the interest of Tigernán Ua Ruairc. ${ }^{51}$ Alongside the list of Dál Cais nobles we have been consid-

\footnotetext{
48 DINNEEN 1908: 156-7: ... amhail fhoillseocham i n-ar ndiaidh do réir an leabhair da ngairthear Cogadh Gall ré Gaedhealaibh 'as we will show below on the authority of the book which is called Cogadh Gall re Gaedhealaibh'.

49 See above

50 Todd 1867: 166-7.

51 Ní Mhaonaigh 1992.
} 
ering are placed troops from the midlands and the north, including three kings of Tethba, the leaders of Conmaicne, Sitric mac Tigernáin of Uí Briúin and Ua Ciarda, king of Cairpre. It was with reference to the assistance provided by these outside groups that the description of the Tuadmumu battalion began; it is clear, therefore, that the author wishes to highlight their participation in the enterprise and this aim links him firmly with the Bréifne-biased Cogadh reflected in the interpolated material preserved in the version of the text in the fourteenth-century Trinity College Dublin manuscript 1319. Fergal Ua Ruairc who died in 966 is presented anachronistically therein as a hero, Murchad mac Briain rising in respect before the northern chieftain. ${ }^{52}$ His role in the battle itself is also portrayed as being pivotal: he and his allies, Domnall mac Ragallaig and Gilla na Náem mac Domnaill Ua Fergail, defeated the king of Liphe and his one thousand men, routing Uí Chennselaig in the process. ${ }^{53}$ The few survivors, including Fergal himself, are supposed then to have joined Murchad's battalion and continued to fight; ${ }^{54}$ we may note that it is in a battalion led by Brian's son that the auxiliary troops are situated in Rawlinson B $486 .{ }^{55}$ Ua Ruairc himself does not appear in the fragment: however, the groups over whom he is presented as presiding, Uí Briúin Bréfne and Conmacne, are prevalent (Conmacne crōdha ceandc[h]assa 7 hI Brūin buadacha); in addition his companions, Ua Ragallaig and Ua Fergail, are specifically named.

Uí Briúin and Conmaicne are joined by Ua Ciarda, king of Cairpre, whose dynasty, Cairbrigh ceanduallca, is also on the Dál Cais side. This stands in marked contrast to both interpolated and uninterpolated versions of the Cogadh in which Uí Chiarda actively oppose Brian. ${ }^{56}$ This and the fact that other northern groups not mentioned in the Cogadh feature in the fragment suggest once more that the Cogadh, as it has survived, was not drawn upon by whoever compiled the Rawlinson B 486 text, though he appears to have had access to a Bréifne-biased source.

\section{The Rawlinson B 486 Text and Leabhar Oiris Compared}

Among the additional names are Ua Gilla Ultáin and Ua Laegacháin; three kings of Tethba are also claimed to have lent support. This information is not preserved in any other early source concerning any of Brian's battles; however, it is repeated in a post-Classical Irish Munster compilation, Leabhar Oiris, the 'Book of Chronicles', which has survived in a number of eighteenth- and nineteenth-century versions. ${ }^{57}$

\footnotetext{
52 ToDD 1867: 156.

53 ToDD 1867: 176 .

54 ToDD 1867: 176.

55 ToDD 1867: 176.

56 The contrast between Ua Ciarda and Ua Ruairc is made explicit in an interpolated passage in the Cogadh (ToDd 1867: 156): ro mallaig Brian andsin Ua Ciarda ocus Carbri, ocus tuc bennacht ar Fergal ocus ar fearaib Brefni archena 'Brian then cursed Ua Ciarda and Uí Chairbri and he blessed Fergal, as well as the men of Bréifne'. The uninterpolated text claims (TodD 1867: 146): faiter fessa ele co Fergal Ua Ruairc co rig Brefni, ocus co hUalgarg Ua Ciarda ri Carbri, ocus foemait sin uli impod ar Brian 'other messengers were sent to Fergal Ua Ruairc, king of Bréifne, and to Ualgarg Ua Ciarda, king of Cairbre and they all agreed to turn against Brian'.

57 Best 1904, based on Royal Irish Academy manuscript 23 E 26 written in 1711 by Seán Mac Solaidh. Meidhbhín Ní ÚRDAIL has noted the existence of twenty-six manuscript versions of this text (Best had cited ten) written between 1711/12 and 1848: Ní ÚRDAIL 2011: 77.
} 
Rawlinson B 486: $§ 6 \quad \ldots \quad 7$ Ō Gilla Ulltāin 7 Ō Læghacāin 7 Ochtrandaigh (?) ${ }^{58}$ trī rīgh fhe ar Teathba, ŌhEolais ${ }_{7}$ Ō Cuind ${ }_{7} \bar{O}(\mathrm{i})$ Raigellaig $h_{7}$ ŌFergail, taíssig Conmacne, 7 Sitriuc mac Tigernāin Ō Briūin 7 Ō Ciard $h a$, rīg $h$ Carbri.

Leabhar Oiris: $:^{59} \quad \ldots 7$ trí rígh Teabhtha 7 Ó Laodhagáin, 7 Giolla Ultáin, 7 Ó Carthanáin, ${ }_{7}$ Conmhaicne 7 Í Bhriain i n-aghaidh chloinne rígh Lochlann, 7 Bhrodair iarla Chaire Ebroc, 7 Sitric mac Lodair iarla Innsi hOrc.

Moreover, in Leabhar Oiris also, these outside troops are said to have assisted Dál Cais chieftains, of whom the few specifically named, with the exception of Cennétig mac Duinn Chuain, are also included in the much longer list of this group in Rawlinson B $486 .^{60}$ The descriptions of the Desmumu battalion which immediately follows this passage in both texts also resemble one another. In fact, it is only with the aid of the later 'chronicle' that we can properly understand the fragment's somewhat elliptical text:

Rawlinson B 486: Ro cōiraighed $h$ cath Briain Dessaman 7 tucadh a dāisigeacht do Domnall mac Duib Dā Boirend ${ }_{7}$ do C $[\mathrm{h}]$ ian mac Maíl Muad $\boldsymbol{h}_{7}$ do raighaibh $\mathrm{O}$ nEathach $\eta_{7}$ is and sin do raighseat Orgialla 7 Fir Manach: 'fota $\mathbf{f}(\boldsymbol{h})$ otuaidh atāmaid(h) $n \mathrm{i}\rceil$ fata $\mathrm{f}(\boldsymbol{h})$ odeass atāit siūt $\uparrow$ cuirim ár $\mathrm{n}$-airm a n-æn inad 7 dēnam bāid $h$ d'æn leit $h$ ' 7 dorōnsat amlaid $h$ sin. Rob iad so ríg $h$ a 7 taīsig .i. Mothla mac Fælāin (i)righ na n[D]en... 7 Muirc[h]ertach mac ${ }^{61}$

Leabhar Oiris: ${ }^{62}$ Cian mac Maoilmhuaidh go maithibh Deasmhumhan 7 shleachta Eoghain Mhóir; 7 Domhnall mac Duibhdábhoireann, rí Chinéil Laoghaire; 7 Mothla mac Faoláin, rí na nDéise; 7 Muircheartach mac Anamchadha, rí Ó Liatháin; 7 Sganlan mac Cathail, rí Locha Léin; 7 Loingseach mac Dúnluing, rí Ó gConaill Ghabhra; 7 Cathal mac Donnabháin rí Ó gCairbre; 7 Mac Beathaigh mic Muireadhaigh, rí Ciarraighe Lúachra; 7 Géibeannach mac Dubhagáin, rí bhFear Muighe; 7 Cearbhall, 7 Ó Ruadhagáin, 7 Ó Dubhghara, trí rígh Oirghíall; 7 Maguidhir rí bhFear Manach, ar n-a rád dhóibh; ó's sinn féin cuideachta is faide budh thuaidh ann so d'Éirinn, rachamaoid i gcath Chéin mic Maoilmhuaidh, ó's é is faide budh dheas d'Éirinn, i n-aghaidh Mhaoilmhórdha mic Murchadha, rígh Laighean, 7 Bhaodhain mic Dúnlaing, rígh Ó gConaill iarthair Laighean, 7 mic Tuathail rígh Liffe, 7 mic Brógáin báinrígh Ó bhFailghe, 7 cath do Lochlannaibh i n-a bhfarradh.

Most striking of all, however, are the close correspondences in the series of twenty kings with which the fragment in Rawlinson B 486 commences and the passage in Leabhar Oiris which follows on from the description of the Desmumu troop. Presen-

58 This conceivably represents a corrupt form of what was originally 'Ó Carthanáin', the form to be expected from the corresponding text of Leabhar Oiris.

${ }^{60}$ The corresponding names are Longbhrogán, Célechair, Fiangalach and Indrechtach: BEST 1904, 85 (\$29).

${ }^{61}$ Owing to a chasm in the manuscript, the text breaks off at this point. On the evidence of Leabhar Oiris and earlier sources concerning Clontarf which list the king of the Déssi and the king of Uí Liatháin side by side, the final name is likely to have been that of Muirchertach mac Anamchada. 
ted in tabular form (in the order of the Rawlinson B 486 fragment on the left), the names read as follows:

\begin{tabular}{|c|c|}
\hline Rawlinson B 486 (§ 1$)$ & Leabhar Oiris $^{63}$ \\
\hline \multicolumn{2}{|l|}{... Briain buad $h$ aigh, bit $h$ beod $h$ a } \\
\hline \multicolumn{2}{|l|}{7 Ceallachān Cend[é]idig comrom $h$ ach Caisil } \\
\hline \multicolumn{2}{|l|}{$\begin{array}{l}7 \text { Mælseachlaind Ō Dondc[h]ad } h \text { a, rīgh } \\
\text { Eoghanacht art[h]eraigh }\end{array}$} \\
\hline $\begin{array}{l}{ }_{7} \text { Ædh h hua Dūngalaig } h \text {, rīgh Mūscraid } h \text { e } \\
\text { Tíre }\end{array}$ & (7) Aodh Guineach Ó Dúngaile \\
\hline \multicolumn{2}{|l|}{${ }_{7}$ Cearball mac Æd $h$ a, rīg $h$ Ēle tuaiscirt } \\
\hline $\begin{array}{l}7 \text { Fōghortach mac Domnaill, rīgh Ēle } \\
\text { deiscirt }\end{array}$ & (8) Fógartach mac Domhnaill, dá rígh Eile ${ }^{64}$ \\
\hline $\begin{array}{l}7 \text { Muirc[h] ertach mac Cuirc, rīgh } \\
\text { Mūscraidhe Breoghain }\end{array}$ & $\begin{array}{l}\text { (9) } 7 \text { Muircheartach mac Cuirc, rí } \\
\text { Muscraighe Bhreoghain }\end{array}$ \\
\hline${ }_{7}$ Æd $h$ mac Loinraghāin, rīg $h$ ua Cuanach & (10) 7 Aodh mac Lochlainn, rí Ó gCuanach \\
\hline 7 Mæl Gu[a]la mac Rind, rīgh Ō nĒnna Āine & (11) 7 Maolrinn, rí Ó nÉnda \\
\hline $\begin{array}{l}7 \text { Dondc[h]ad } h \text { mac meic C[h]athail, rígh } \\
\text { Mūscraidhe } \mathrm{h} Æ d h \mathrm{a}\end{array}$ & $\begin{array}{l}\text { (12) } 7 \text { Donnchadh mac Cathail, rí } \\
\text { Muscraighe hAodha }\end{array}$ \\
\hline \multicolumn{2}{|l|}{${ }_{7}$ Æd $h$ mac Flaind, rīgh Mūscraighe Mitaine } \\
\hline $\begin{array}{l}7 \text { Domnall mac Diarmada, rīgh Corco } \\
\text { Baisscind airt [h] araigh }\end{array}$ & $\begin{array}{l}\text { (13) } 7 \text { Domhnall mac Diarmoda, rí } \\
\text { Chorcabaiscne }\end{array}$ \\
\hline \multicolumn{2}{|l|}{$\begin{array}{l}7 \text { mac Andsa meic Baisscind, rīg } h \text { Corco } \\
\text { Baisscind iart [h]araigh }\end{array}$} \\
\hline $\begin{array}{l}7 \text { Aichtighearnd mac Dondacāin, rīgh } \\
\text { Arad } h\end{array}$ & $\begin{array}{l}\text { (14) } 7 \text { Eachtighearn mac Don[n]agáin, rí } \\
\text { Aradh }^{65}\end{array}$ \\
\hline${ }_{7}$ Cathal mac Concubhair, rīgh Conacht & (1) Cathal mac Conchubhair, rí Connacht \\
\hline 7 Mæl Ruanaid $h$ Ō hEdin, rīgh Aid $h$ ne & (2) 7 Maoilruanaidh Ó hEidhin, rí Aidhne \\
\hline $\begin{array}{l}7 \text { Æd } h \text { Ō F }(h) \text { lait } h \text { bertaig } h \text {, rīg } h \text { Muintire } \\
\text { Murchadha }\end{array}$ & $\begin{array}{l}\text { (4) } 7 \text { Aodh Ó Flaithbheartaigh, rí } \\
\text { Mhuinntire Mhurchadha }\end{array}$ \\
\hline 7 Tadg Ō Cellaigh, rí Ō Maine & (3) 7 Tadhg Ó Ceallaigh, rí Ó Maine \\
\hline $\begin{array}{l}7 \text { Conc[h]ubhar Ō Maílruanaid, rīgh } \\
\text { Muighe Luirg }\end{array}$ & $\begin{array}{l}\text { (5) } 7 \text { Conchubhair Ó Maoilruanaidh, rí } \\
\text { Muighe Luirg }\end{array}$ \\
\hline $\begin{array}{l}7 \text { Muirc }[\mathrm{h}] \text { ertach mac Cadla, rīgh } \\
\text { Conmacne Mara }\end{array}$ & $\begin{array}{l}\text { (6) } 7 \text { Muircheartach Ó Ceallaigh, rí } \\
\text { Chonmhaicne Mara }^{66}\end{array}$ \\
\hline
\end{tabular}

\footnotetext{
${ }^{63}$ BEST 1904: 86 (§31). The corresponding passage in the Egerton 106 version of Cath Cluana Tarbh reads as follows: 'Agus do bhí san treas cath le Brian .i. Cathal Ua Conchubhair Rí Connacht, agus Maol Ruadhanaidh Ó hEidhin Rí Áine, agus Tad[h]g Ua Ceallaigh Rí Ua Maine, agus Aodh Ua Flaithbheartaigh Rí Muinntire Mhurchadha, agus Conchubhar Ua Maoil Ruanaidh Rí Mhuighe Luirg, agus Muircheartach Ō Cadhla Rí Conmhaicne Mara, agus dhá rígh Éile, agus Muircheartach mac Cuirc Rí Musgraighe Breōg[h]ain, agus Aodh mac Lochlainn Rí Ō gCuanach, 7 Donnchad[h] mac Cathail Rí Musgraighe hAodha, agus Domhnall mac Diarmada Rí Corca Baisgne, agus Eichthighearn mac Donnagāin Rí Ara, i n-aghaidh Ghall Âtha Cliath agus dhā c[h]éad déag do Lochlannachaibh 'na bhfarradh.': Ní ÚRDAIL 2011: 110; for variant versions, see 165, 179. I am grateful to Dr Ní ÚRDAIL for providing me with access to the passages I cite from her edition prior to its publication.

${ }^{64}$ Fógartach and the preceding Áed Guinech are the 'two kings' in question.

${ }^{65}$ Echthigern concludes the list in Leabhar Oiris; his name is followed by the phrase in-aghaidh Gall Âtha Cliath, 7 dá chath oile Lochlannach 'n-a bhfarradh.

${ }^{66}$ Followed by 7 cuid do ríghraidh Mumhan annsa chath so i. at which point the list proceeds again with Áed Guinech.
} 
The names fall into two natural groups, those of Munster and Connacht kings, presented in reverse order in the two texts but with the inversion of Áed Ua Flaithbertaig and Tadc Ua Cellaig apart, in the same order. That Brian's name should head the list in the Rawlinson B 486 fragment is understandable since the passage is found at the beginning of the narrative. Why Cellachán of Cashel who died long before the battle of Clontarf ${ }^{67}$ and who seems to be conflated with Brian's own father, Cennétig, as well as the Eóganacht king, Máel Sechnaill Ua Donnchada, should be presented as Brian's right-hand men is unclear. The remaining core of the list is undoubtedly based on the same source which the later text Leabhar Oiris appears to preserve most faithfully. Thus, the three supplementary names in the Rawlinson B 486 fragment are best explained as additions in that text. The division of Corco Baiscinn into eastern and western territories would have necessitated the provision of an extra royal name, that of the otherwise unattested (and somewhat suspiciously named) son of Annsa mac Baiscinn. Áed mac Flainn, king of Múscraige Mittaine, can be explained with reference to the general interest in Múscraige territories exemplified by the Rawlinson B 486 scribes $^{68}$ as can the insertion of Cerball mac Áeda, presumably a son of the man preceding him, Áed mac Dúngalaig, king of the scribe's home territory of Múscraige Tíre. Significantly, Cerball is described as king of the neighbouring territory of northern Éile. A member of Dál Cais, ${ }^{69}$ Fógartach mac Domnaill, is listed as his counterpart in southern Éile. He also features in Leabhar Oiris where he is coupled with Cerball mac Áeda's father, Áed Guinech, both being described as kings of an undivided Éile.

\section{Conclusion}

Thus, the list of kings with which our fragment opens is strikingly similar to a list forming part of the description of Brian's allies immediately preceding the account of the battle in the eighteenth-century Munster text, Leabhar Oiris. ${ }^{70}$ The description of the Desmumu battalion in both texts also share common features, though as only two or three sentences of this section survive in our fragment, firm conclusions are difficult to draw. There are also correspondences in the names of some of those listed in the Tuadmumu battalion (described as Murchad mac Briain's allies in the later text); thus Tethba, Uí Briúin and Conmaicne occur in both the Rawlinson B 486 text and the later Munster chronicle. ${ }^{71}$ Mention of Uí Briúin and Conmaicne echo information contained in material interpolated into Cogadh Gáedhel re Gallaibh in the middle of the twelfth century, though the parallels are not particularly striking in this instance. This stands in contrast to other passages in this section of the text, specifically those introducing Dál Cais and Murchad mac Briain, which repeat for the most part verbatim, material also preserved in the earlier Uí Briain tract. The two accounts subsequently diverge, the author of the fragment drawing on genealogical material for his detailed list of Dál Cais nobles included in the battalion. It seems

\footnotetext{
${ }^{67}$ AI 954: Quies Duib Inse, sui-eps[coip] Herend, 7 Cellacháin, ríg Cassil ...

${ }^{68}$ See above.

${ }^{69}$ CGH: 241 (Rawlinson B 502, 153 a 44).

70 Meidhbhín Ní ÚRDAIL has suggested that Leabhar Oiris was compiled in the first quarter of the eighteenth century: Ní ÚRDAIL 2005a: 108. These correspondences, as we have seen, are also present in the core text of Cath Cluana Tarbh.

${ }^{71}$ However, these are not found in the core text of Cath Cluana Tarbh.
} 
likely, however, that a version of the Cogadh was drawn on by the author, though it was not identical with the one recension of that text detailing the Clontarf encounter to have survived.

About nine of the Dál Cais names in the genealogical list are also found in Leabhar Oiris in the description of Murchad's battalion and in some versions of the postClassical Irish retelling of the battle of Clontarf. ${ }^{72}$ Significantly, these later sources continue in the same vein as the Rawlinson B 486 fragment with reference to Connacht and midland sources before moving on to describe the Desmumu battalion under Domnall mac Duib Dá Boirenn and Cian mac Maíl Muaid. Structurally too the Rawlinson B 486 text can be compared with those later works, since it is with an enumeration of battalions that the 1014 entry in Leabhar Oiris and what Meidhbhín Ní Úrdail has termed the core text of Cath Cluana Tarbh also begin. ${ }^{73}$ Rawlinson B 486 omits any reference to the enemy forces with which the eighteenth- and nineteenthcentury texts commence. Nonetheless, it provides important evidence for the existence already in the fourteenth century of the prototype of what have survived as post-Classical Irish Clontarf texts and which appears to be represented most faithfully in Leabhar Oiris, as it has survived. The Munster focus of the latter could explain why the geographically disparate group of Brian's allies with which the Rawlinson B 486 fragment begins appears as the third of Brian's battalions in the later chronicle, taking up the rear behind Murchad mac Briain's assorted Dál Cais and other forces, and the army comprising mainly Munster neighbours led by Desmumu kings. In any event, notwithstanding their varying position in the narrative, the core list of fourteen kings common to Leabhar Oiris and our fragment undoubtedly derive from a very similar source.

Given their close connection, it is tempting to use Leabhar Oiris to reconstruct the now lost ending of the Rawlinson B 486 fragment. It seems likely that it once contained the other names assigned to the Desmumu battalion in Leabhar Oiris, since these precede the reordered common list of allies in the chronicle text. Having enumerated those far-flung supporters, the battle proper can begin and the climax of the Rawlinson B 486 narrative was also in all probability the military encounter itself. The detail with which it was related or the particular aspects of the multi-faceted conflict upon which the author dwelt cannot now be recounted, but this illuminating fragment undoubtedly constitutes, as Brian Ó Cuív noted, 'an account of the Battle of Clontarf', and an important one at that.

\footnotetext{
72 ' $\{$ AGUS $\}$ Toirrdhealbhach mac Taidhg, \{AGUS $\}$ Domhnall mac Conchubhair, \{AGUS Flann, ceithre meic oile Briain, \{AGUS $\}$ clann Duinnchuain, Longbhrogan, \{AGUS $\}$ Céiliochair, \{AGUS $\}$ Ceannéidigh, \{AGUS $\}$ Fianghalach, \{AGUS $\}$ Ionnrachtach go maithibh Dháil gCais uime agus Thuathmhumhan’: Best, Leabhar Oiris, 85 (§29). A better reading is preserved in Cath Cluana Tarbh: '... Tadhg, Domhnall, Conchúbhar \{AGUS\} Flann ceithre mic eile do Bhrian, \{AGUS\} Donnchuan mac Cinnéide, Lonargán, Céiliochair, Fiongalla \{AGUS \} Iónnrachtach do $\mathrm{m}[\mathrm{h}$ ] aithibh Dail gCais agas Tuamhan umpa': Ní ÚRDAIL 2011: 219; see also MAC NeILL 1896-7: 8 .

${ }^{73}$ Ní Úrdail 2005b; see also Ní Úrdail 2011: 36-7 in particular.
} 
§1 Ro cōiraighed $h$ ar dūs cat $h$ Brian 7 tiac $(h)$ aith and Eog hanacht Cendēidig comra mach Caisil ${ }_{7}$ Sìl cæm $h$, crōdha Conaire 7 cūiced $h$ ceanard, cocctach, congalach Conacht 7 cetherri[a]da crōdha, $\operatorname{cocc}(\mathrm{a}) \mathrm{t} h \mathrm{ach}{ }_{7}$ amais borrba, borfadhach Bria[i] $n_{7}$ Domna(i)ll mac Eimín mōrmær Alban 7 a muintear ime. Et rob íad so rīgha (rīgha) in c[h]ath[a] $\sin$ Briain buadhaigh, bit $h$ beod $h$ a:

(7) Ceallachān Cend[é]idig comromhach Caisil

7 Mælseachlaind Ō Dondc[h]adha, rīg $h$ Eoghanacht art[h]eraig $h$

${ }_{7} Æ \mathrm{~d} h$ hua Dūngalaig $h$, rīg $h$ Mūscraidhe Tíre

${ }_{7}$ Cearball mac Ædha, rīg $h$ Ēle tuaiscirt

${ }_{7}$ Foghortach mac Domnaill, rīg $h$ Ēle deiscirt

7 Muirc[h]ertach mac Cuirc, rīgh Mūscraidhe Breoghain

7 Æd $h$ mac Loinrag $h a ̄ i n$, rīg $h$ ua Cuanach

7 Mæl Gu[a]la mac Rind, rīg $h$ Ō nĒnna Āine

${ }_{7}$ Dondc[h]adh mac meic C[h]athail, ríg $h$ Mūscraidhe $\mathrm{h} Æ d h \mathrm{a}$

7 Æd $h$ mac Flaind, rīgh Mūscraighe Mitaine

${ }_{7}$ Domnall mac Diarmada, rīg $h$ Corco Baisscind airt[h] araigh

$7 \mathrm{mac}$ Andsa meic Baisscind, rīgh Corco Baisscind iart[h]araigh

${ }_{7}$ Aicht[h]ighearnd mac Dondacāin, rīgh Arad $h$

${ }_{7}$ Cathal mac Concubhair, rìgh Conacht

7 Mæl Ruanaid $h$ Ō hEdin, rīg $h$ Aid $h$ ne

${ }_{7} Æ \mathrm{~d} h \mathrm{O} F(h)$ lait $h$ bertaig $h$, rīg $h$ Muintire Murchad $h$ a

7 Tadg Ō Cellaigh, rí Ō Maine

7 Conc[h]ubhar Ō Maílruanaid, rīgh Muighe Luirg

7 Muirc[h]ertach mac Cadla, rīgh Conmacne Mara.

§2 Ro cōraighed $h$ cath Tuadhaman ar sin fan cuma cétna 7 tecait ind tæb $h$ taigh trēna, 25 tairbeacha ${ }_{7}$ Conmacne crōdha, ceandc[h] assa 7 hÍ Br[i]ūin buadacha ${ }_{7}$ Cairbrigh ceanduallc[h] a 7 Said $h$ nig særa, snuadamla ${ }_{7}$ Sīl Ædha saír Slāine 7 rob iat so rīgha 7 toīssigh in c[h] atha sin.

§ 3 Tucad $h$ a dosach don damraig $h$ dēin, dīfhuiling, dīchra 7 don gamanraid $h$ glain, gasta, gērata, galaigh, gnīmaigh gairgbeodha .i. do Dāil Caiss curata, comramaigh 7 do 30 $\mathrm{C}[\mathrm{h}] \mathrm{la}(\mathrm{i}) n$ daib $h$ Luig $h$ dheach $\operatorname{arc}[\mathrm{h}]$ eana.

§4 Ro baī rompu sin Achtair indtamlaighteach na hĒrend 7 na hĀdhamhc[h]lainde ilc[h]enēalaigh, allata $\operatorname{arc}[\mathrm{h}]$ eana .i. Murcad $h$ mac Briain, eo rosa raicg $h$ daid $h e(?)$ na

\footnotetext{
1 Ro] The text begins a new page in the manuscript and the first ' $\mathrm{R}$ ' has some decoration. 1 Cendèidig] Subscript mark over 'i' rather than ' $\mathrm{d}$ ' in this and other examples of this name.. 16 Corco] The first column ends here.. 17 Baisscind] Superscript 'ci' with suspension stroke above it.. $20 \mathrm{Mæl}$ ] A letter is scrubbed out in the manuscript before 'M'.. 24 Mara] 'Mara' is in the margin.. $25 \mathrm{Ro}$ ] The initial 'R' has some red decoration.. 29 Tucadh] The initial ' $T$ ' has some yellow decoration.. $32 \mathrm{Ro}$ ] The initial ' $\mathrm{R}$ ' is filled in with red. It marks the beginning of a new line, the end of the previous line after 'ceana' having been left blank.. 33 eo] Beginning of new page 36vl. 'Bri aín' is at the end of the previous page in the bottom margin.. 33 raicghdaidhe (?)] The ' $\mathrm{i}$ ' is superscript and what might be a ' $\mathrm{c}$ ' is subscript. It may be a corrupt form of rígraide, gen. sg. of rígrad 'kings, princes', which is the corresponding form in the Cogadh..
} 


\section{Translation}

$\S 1$ Brian's battalion was arranged first: the Éoganacht of contentious Cennétig of Cashel join it, beautiful, brave Síl Conaire and the proud, warlike, valiant Connachta; brave, warlike chariots and the fierce, ferocious mercenaries of Brian; and Domnall mac Emín, mórmáer of Alba, together with his retinue. These were the kings of that battalion of victorious, ever-vibrant Brian:

Contentious Cellachán Cennétig of Cashel

Máel Sechnaill Ua Donnchada, king of eastern Éoganacht

Áed Ua Dúngalaig, king of Múscraige Tíre

Cerball mac Áeda, king of northern Éile

Fogortach mac Domnaill, king of southern Éile

Muirchertach mac Cuirc, king of Múscraige Breogain

Áed mac Loinragáin, king of Ua Cuanach

Máel Guala mac Rind, king of Uí Énna Âine

Donnchad mac meic Cathail, king of Múscraige Áeda

Áed mac Flainn, king of Múscraige Mittaine

Domnall mac Diarmata, king of eastern Corco Baiscinn

mac Annsa meic Baiscinn, king of western Corco Baiscinn

Echthigern mac Donnacáin, king of Ara

Cathal mac Conchobair, king of Connacht,

Máel Ruanaid Ua hEidin, king of Aidne

Áed Ua Flaithbertaig, king of Muinter Murchada

Tadc Ua Cellaig, king of Uí Maine

Conchobar Ua Maíl Ruanaid, king of Mag Luirg

Muirchertach mac Cadla, king of Conmaicne Mara

§ 2 The battalion of Tuadmumu was arranged after that in the same way: the strong, stout supporters came and courageous, curly-haired Conmaicne; victorious Uí Briúin; haughty Cairbre; noble, comely Saidne; as well as noble Síl nÁeda Sláine. And these were the kings and leaders of that battalion.

$\S 3$ Precedence was given to the alert, irresistible, eager company, to the pure, vibrant, valiant, valorous, active, mettlesome and lively band, i.e. to brave, battlesome Dál Cais and to Clanna Luigdech besides.

$\S 4$ Leading them was Ireland's counterpart to Hector and that of the renowned, raciallyrich family of Adam besides, namely Murchad mac Briain, the yew of Ross of the 


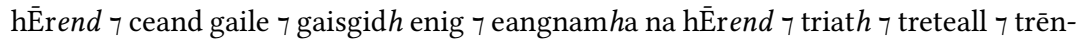
mílid $h$ fhe $a r$ in talman re ræ 7 re roimeas. Dōig ni ármid seanc[h]aidhe na [n]Gædheal 35 co m[b]eth donn Ādham $h$ c[h]laind 'na aimsir fēin æn duine ro congēbad $h$ sciat $h$ co freastal imuallta fris. 7 Baí ar æn fris a mac fēin .i. Toirdelbach in mac aissi 7 in rīghdomna is fearr ro baí a nĒrind.

§5 7 Tānic mac Duind Cuan mac brāthar Bria[i]n, in mac is doch(i)u le Brian baí in hĒrind .i. tromtānaistte na hĒrend 7 rīgh díles Desumhan; 7 Níall Ō Cuind 740 Eochaid $h$ Ō Dūnaghaid $h$, flait $h$ Clainde Scandlāin ${ }_{7}$ Cū Duilig $h$ mac Ceindēdig $h$, trī cūlc[h]oimēd $h$ aig $h$ Briain.

§6 7 Ceindēdig $h_{7}$ Dund Cuan, Aichtighearnd $h_{7}$ Ānluan;

${ }_{7}$ Coscrach mac Lorcāin cona (a)c[h]laind (7) Seanc[h]ān ${ }_{7}$ Ōgān ${ }_{7}$ Mæl Ruanaid $h_{7}$ Angid $h$;

Tadg ${ }_{7}$ Domnall ${ }_{7}$ Conc $\left[\right.$ h] ubhur ${ }_{7}$ Fland;

7 Meanma Adhar 7 Dedadh mac Domnaill ${ }_{7}$ Mæl Meadha mac Gilla Bædāin 7 Don $n c[\mathrm{~h}] \mathrm{ad} h{ }_{7}$ Domnall ${ }_{7}$ Gilla Pātraic 7 Gormgall 7 Cathān;

${ }_{7} \mathrm{Du}(\mathrm{i}) n \mathrm{~d}$ Cuan, Longargān 7 Rígruan ${ }_{7}$ Cèlechair;

${ }_{7}$ Fiangalach ${ }_{7}$ Indrachtach; 7 Dui(d)[b]c[h]eand ${ }_{7}$ Beollān; 7 Ruaidhrí mac Cētfadha 50

7 Níall buidhi mac Indrachtaigh 7 Raghnall mac Ōgāin ${ }_{7}$ Cuilēn mac Cathalāin 7 Eochaid $h$ ua Longsig $h_{7}$ Mælseachlaind mac Conc[h]ubhu[i]r, rīgh Corcu Mruad $h$ íart[h] arach 7 Amlaim $h$ mac Lochlaind, rīgh Coru Mruad $h$ airt[h] arach 7 Aichear mac Lorcāin, rīgh Ō Cormeic;

${ }_{7}$ Ō Gilla Ulltāin ${ }_{7}$ Ō Læg hacāin ${ }_{7}$ Ochtrandaigh $h$ trī rīgh fhear Teat $h$ ba, Ō hEolais 755 ŌCuind ${ }_{7}$ Ō(i) Raigellaigh ${ }_{7}$ ŌFergail, taíssig Conmacne, 7 Sitriuc mac Tigernāin Ō Briūin $\urcorner_{7}$ Ō Ciard ha, rīgh Carbri.

$\S 7$ Ro cōiraighed $h$ cat $h$ Briain Dessaman 7 tucad $h$ a daīsigeacht do Domnall mac Duib Dā Boirend ${ }_{7}$ do C[h]ian mac Maíl Muad $h_{7}$ do r(a)īghaib $h$ O nEathach $h_{7}$ is and sin do rāig $h$ seat Orgialla 7 Fir Manach: 'fota $\mathrm{f}(h)$ otuaidh atāmaid(h) $n \mathrm{i}\rceil$ fata $\mathrm{f}(h)$ odeass atāit ${ }_{60}$ siūt 7 cuirim ár n-airm a n-æn inad 7 dēnam bāid $h$ d'æn leit $h$ ' 7 dorōnsat amlaid $h$ sin. Rob iad so rígha 7 taīsig .i. Mothla mac Fælāin (i)rīgh na n[D]en... 7 Muirc[h]ertach $\mathrm{mac}$

35 Dōig] ' $\mathrm{D}$ ' is larger than the other capitals and has red decoration.. 39 doch $(i) u$ ] Superscript ' $\mathrm{i}$ ' above 'c'.. 46 Tadg] Superscript 'd' above 'g'.. 49 Rígruan] Superscript 'u' above 'g'.. 51 7] The first column ends here.. 55 Ochtrandaigh] Lenition mark over the ' $t$ ' rather than the 'c'. It may be a corrupted form of Ó Carthanáin, the name to be expected on the evidence of the corresponding text in Leabhar Oiris.. $\quad 58$ Ro] This large initial ' $R$ ' is decorated in red. It begins a new line and the remainder of the previous line is deliberately left blank.. $\quad \mathbf{6 0}$ atämaid(h)ni] Suspension stroke above previous 'i'.. $\quad 62 R o b$ ] Initial 'R' filled in with red; the remainder of the previous line is left blank.. $62 n[D] e n . .$.$] Writing in margin of page and is illegible; perhaps cht suspension stroke with$ dot over it followed by 'i'?. $63 \mathrm{mac}$ ] The ' $\mathrm{m}$ ' is a smudge at the very end of the page.. 
kings (?) of Ireland; the most outstanding in valour and weaponry, in status and skill in Ireland; and the lord, leader and strong warrior over the men of the world in his time and period. For the historians of the Irish do not relate that there was among the human race anybody who could hold a shield to him in a battle exchange with him in his own era. His own son was accompanying him, namely Toirdelbach, the best son of his age and heir-apparent who was in Ireland.

$\S 5$ Donn Cuan's son, the son of Brian's brother, arrived, the most in Ireland whom Brian preferred most, namely the strong second-in-command (tánaise) of Ireland and the loyal king of Desmumu; together with Níall Ua Cuinn, Eochaid Ua Dúnagaid, the leader of Clann Scannláin, and Cú Duilig mac Cennétig, Brian’s three rear-guards.

§ 6 Cennétig, Donn Cuan, Echthigern and Ánluan;

and Coscrach, sons of Lorcán, together with their families (and) Senchán, Ócán, Máel Ruanaid and Angid;

Tadc, Domnall, Conchobar and Flann;

Menma Adair, Dedad mac Domnaill, Máel Meda mac Gilla Bedáin, Donnchad, Domnall and Gilla Pátraic, Gormgal and Cathán;

Donn Cuan, Longargán, Rigruan and Célechair;

Fiangalach and Indrachtach; Duibchenn and Beollán; Ruaidrí mac Cétfada,

Níall buide mac Inrechtaig, Ragnall mac Ócáin, Cuilén mac Cathaláin,

Eochaid Ua Loingsig, Máel Sechnaill mac Conchobar, king of western Corcu Mruad, Amlaíb mac Lochlainn, king of eastern Corcu Mruad and Aicher mac Lorcáin, king of Uí Chormaic;

Ua Gilla Ultáin, Ua Láegacáin, Ua Carthanáin (?), three royal men of Tethba, Ua Eolais, Uí Chuinn, Uí Raigellaig, Uí Fhergail, leaders of Conmaice, Sitriuc mac Tigernáin,

Uí Briúin, Uí Chiarda, kings of Cairbre.

§ 7 Brian's battalion of Desmumu was arranged: precedence was given to Domnall mac Duib dá Boirenn, to Cian mac Maíl Muaid and to the kings of Uí Echach. It was then Oirgialla and Fir Manach said 'we are a long way up in the north and they are a long way down in the south, let us put our weapons in one spot and let us make peace in one place' and it was done thus. These are the kings and leaders: Mothla mac Fáeláin, leader of the ... and Muirchertach mac ...

\section{Bibliography}

AFM: John O'Donovan, ed. and trans., Annála ríoghachta Éireann, Annals of the kingdom of Ireland by the Four Masters from the earliest period to the year 1616. 7 Vols. $2^{\text {nd }}$ edn. Dublin: Hodges, Smith \& co., 1848-56.

AI: Seán MAc AIRT, ed. and trans., The Annals of Inisfallen (MS. Rawlinson B. 503). Dublin: Dublin Institute for Advanced Studies, 1951.

ALC: William M. Hennessy, ed. and trans., The Annals of Loch Cé: a chronicle of Irish affairs from A.D. 1014 to A.D. 1590.2 vols. London: Longman \& co. and Trübner \& co., 1871.

AU: Seán Mac Airt \& Gearóid Mac Niocaill, eds and trans., The Annals of Ulster (to A.D. 1131), Part I, text and translation. Dublin: Dublin Institute for Advanced Studies, 1983.

BEst, R.I., ed. 1904: ,The Leabhar Oiris', Ériu 1, 74-112 
CGH: M.A. O’Brien, ed., Corpus Genealogiarum Hiberniae. Vol. 1. Dublin: Dublin Institute for Advanced Studies, 1976.

DIL: E.G. QUIN, general editor, Dictionary of the Irish Language based mainly on Old and Middle Irish materials. Compact edition. Dublin: Royal Irish Academy, 1988.

DinneEn, P.S., ed. and trans., 1908: Foras Feasa ar Éirinn le Seathrún Céitinn, D.D., an treas imleabhar i $n-a$ bfhuil an dara leabhar den stair; The History of Ireland by Geoffrey Keating, D.D., volume III containing the second book of the history. Irish Texts Society IX. London: Irish Texts Society.

CS: William M. Hennessy, ed. and trans., Chronicum Scotorum, a chronicle of Irish affairs, from the earliest times to A.D. 1135 with a supplement containing the events from 1141 to 1150 . London: Longmans, Green, Reader, \& Dyer.

Hudson, Benjamin, 2006: Irish Sea studies 9oo-120o. Dublin: Four Courts Press.

GoedheER, A.J., 1938: Irish and Norse traditions about the Battle of Clontarf. Nederlandsche bijdragen op het gebied van germaansche philologie en linguistiek 9. Haarlem: H.D. Tjeenk Willink \& zoon.

LL: R.I. Best \& M.A. O’BRIEN, eds, The Book of Leinster, formerly Lebar na Núachongbála. Vol. 5. Dublin: Dublin Institute for Advanced Studies, 1957.

MAC NeILL, John, ed., 1896-7: ,Cath Cluana Tairbh', Irisleabhar na Gaedhilge: The Gaelic fournal 7, 8-11, 41-44, 55-57.

Murphy, Denis, ed., 1896: The Annals of Clonmacnoise being Annals of Ireland from the earliest period to A.D. 1408 translated into English A.D. 1627 by Conell Mageoghagan. Dublin: Royal Society of Antiquaries of Ireland.

Ní Mhaonaigh, Máire, 1992: „Bréifne bias in Cogad Gáedel re Gallaib’, Ériu 43, 135-158.

Ní Mhaonaigh, Máire, 1996: ,Cogad Gáedel re Gallaib and the annals: a comparison', Ériu 47, 101-126.

Ní Mhaonaigh, Máire, 2007: Brian Boru: Ireland's greatest king? Stroud: Tempus.

Ní ÚrdaIl, Meidhbhín, 2005a: , Annála Inse Faithleann an ochtú céad déag agus Cath Chluain Tarbh', Eighteenth-century Ireland: Iris an Dá Chultúr 20, 104-119.

Ní ÚrDAIL, Meidhbhín 2005b: ,Seachadah Cath Cluana Tarbh sna lámhscríhinní, Léachtaí Cholm Chille 34, 179-215.

Ní ÚrdaIl, Meidhbhín, ed. and trans., 2011: Cath Cluana Tarbh 'The Battle of Clontarf', Irish Texts Society LXIV. Dublin: Irish Texts Society.

Ó Cuív, Brian 2001: Catalogue of Irish language manuscripts in the Bodleian Library at Oxford and Oxford College libraries, Part I, descriptions. Dublin: Dublin Institute for Advanced Studies.

Ó DonnchadhA, Tadhg, ed., 1940: An Leabhar Muimhneach maraon le suim aguisíní. Dublin: Irish Manuscripts Commission.

O'Grady, Standish Hayes, ed. and trans., 1929: Caithréim Thoirdhealbhaigh, the triumphs of Turlough. 2 Vols. Irish Texts Society XXVI, XXVII. London: Irish Texts Society.

Ó RIAIn, Pádraig, ed., 1985: Corpus genealogiarum sanctorum Hiberniae. Dublin: Dublin Institute for Advanced Studies.

Simms, Katharine, 1979: ,The battle of Dysert O’Dea and the Gaelic resurgence in Thomond', Dál gCais 5, 59-66.

Sveinsson, Einar Ólafur, ed., 1954: Brennu-Njáls saga. Íslenzk fornrit 12. Reykjavík: Hi íslenzka Fornritfélag.

STokes, Whitley, ed., 1896: ,The Annals of Tigernach', Revue celtique 17, 6-33, 119-263, 337-420.

ToDD, James Henthorn, ed. and trans., 1867: Cogadh Gaedhel re Gallaibh: the war of the Gaedhil with the Gaill, or the invasions of Ireland by the Danes and other Norsemen. London: Longmans, Green, Reader \& Dyer.

University of Cambridge

Máire Ní MHAONAIGH

Department of Anglo-Saxon, Norse, and Celtic 